\title{
Adaptation of Mycoplasmas to Antimicrobial Agents: Acholeplasma laidlawii Extracellular Vesicles Mediate the Export of Ciprofloxacin and a Mutant Gene Related to the Antibiotic Target
}

\author{
Elena S. Medvedeva, ${ }^{1}$ Natalia B. Baranova, ${ }^{1}$ Alexey A. Mouzykantov, ${ }^{1}$ \\ Tatiana Yu. Grigorieva, ${ }^{1}$ Marina N. Davydova, ${ }^{1}$ Maxim V. Trushin, ${ }^{1,2}$ \\ Olga A. Chernova, ${ }^{1,2}$ and Vladislav M. Chernov ${ }^{1,2}$ \\ ${ }^{1}$ Kazan Institute of Biochemistry and Biophysics, Kazan Scientific Centre of Russian Academy of Sciences, Kazan 420111, Russia
${ }^{2}$ Kazan Federal University, Kazan 420008, Russia
}

Correspondence should be addressed to Vladislav M. Chernov; chernov@mail.knc.ru

Received 17 November 2013; Accepted 18 December 2013; Published 29 January 2014

Academic Editors: A. El-Shibiny and D. Zhou

Copyright (c) 2014 Elena S. Medvedeva et al. This is an open access article distributed under the Creative Commons Attribution License, which permits unrestricted use, distribution, and reproduction in any medium, provided the original work is properly cited.

\begin{abstract}
This study demonstrated that extracellular membrane vesicles are involved with the development of resistance to fluoroquinolones by mycoplasmas (class Mollicutes). This study assessed the differences in susceptibility to ciprofloxacin among strains of Acholeplasma laidlawii PG8. The mechanisms of mycoplasma resistance to antibiotics may be associated with a mutation in a gene related to the target of quinolones, which could modulate the vesiculation level. A. laidlawii extracellular vesicles mediated the export of the nucleotide sequences of the antibiotic target gene as well as the traffic of ciprofloxacin. These results may facilitate the development of effective approaches to control mycoplasma infections, as well as the contamination of cell cultures and vaccine preparations.
\end{abstract}

\section{Introduction}

The suppression of mycoplasmas that infect humans, animals, and plants, as well as contaminating cell cultures and vaccines, is a serious problem [1-3]. This is because mycoplasmas rapidly acquire resistance to antibiotics. However, antibiotic therapy remains the primary tool used for the treatment of mycoplasma infections and the decontamination of cell cultures. The most widely used fluoroquinolones, which are synthetic antibacterials, are enrofloxacin, sparfloxacin, ofloxacin, ciprofloxacin, and levofloxacin [3-5]. The mechanisms that facilitate the rapid development of resistance to fluoroquinolones in mycoplasmas remain unclear $[6,7]$. The development of resistance to quinolones is associated with mutations in genes that encode antibiotic-targeted proteins, and a limitation is that the antibiotics used to treat microbial cells are not considered to be effective against mycoplasmas
$[4,8]$. Thus, it would be beneficial to elucidate the mechanisms that facilitate the rapid development of antibiotic resistance to allow the treatment of mycoplasma infections, which appear to be associated with the adaptation of mycoplasmas to stress conditions $[9,10]$. The successful implementation of genome projects for a number of mycoplasmas has opened up the possibility of using postgenomic technologies to study their antibiotic resistance processes [11, 12].

A unique species of mycoplasma with adaptive properties is Acholeplasma laidlawii, which is a causative agent of phytomycoplasmoses and the main contaminant of cell cultures and vaccines $[2,13,14]$. In our study $[9,10]$, transcriptomeproteome analysis and nanoscopy were identified as the stress-reactive proteins and genes of Acholeplasma laidlawii, which showed that the adaptation of this mycoplasma to stressful factors was related to the production of extracellular vesicles (EVs). The EVs of bacteria are spherical 
nanostructures surrounded by a membrane (20-200 $\mathrm{nm}$ in diameter), which mediate the traffic of a wide variety of compounds that participate in signaling, intercellular interactions, and pathogenesis $[15,16]$. Recent studies suggest the possible involvement of EVs in the development of resistance to antibiotics in bacteria $[17,18]$. However, there are no previous studies of the roles of EVs in antibiotic resistance in mycoplasmas. Thus, the present study demonstrated the participation of A. laidlawii EVs in the development of resistance to fluoroquinolones (ciprofloxacin).

\section{Materials and Methods}

2.1. Bacterial Strain and Plasmids. Acholeplasma laidlawii PG8 (from the N.F. Gamalei Research Institute of Epidemiology and Microbiology, Moscow, Russia), clinical isolate of Staphylococcus aureus, E. coli NovaBlue strain, and plasmid vector pGEM-T Easy Vector Systems (Promega) were used in this work.

2.2. Cultivation of A. laidlawii. A. laidlawii PG8 cells were cultivated for 1 day at $37^{\circ} \mathrm{C}$ in Edward's medium (tryptose, $2 \%(\mathrm{w} / \mathrm{v}) ; \mathrm{NaCl}, 0.5 \%(\mathrm{w} / \mathrm{v}) ; \mathrm{KCl}, 0.13 \%(\mathrm{w} / \mathrm{v})$; Tris base, $0.3 \%(\mathrm{w} / \mathrm{v})$; serum of horse blood, $10 \%(\mathrm{w} / \mathrm{v})$; fresh yeast extract, $5 \%(\mathrm{w} / \mathrm{v})$; glucose solution, $1 \%(\mathrm{w} / \mathrm{v})$; benzylpenicillin $\left.\left(500,000 \mathrm{IE} \mathrm{mL}^{-1}\right), 0.2 \%(\mathrm{w} / \mathrm{v})\right)$ to obtain the control cells. To obtain ciprofloxacin-resistant clones, a mycoplasma culture was grown from a single colony of the laboratory A. laidlawii PG8 strain and sequentially inoculated in a broth medium that contained increasing concentrations of the antibiotic. To determine the minimal inhibitory concentration (MIC) of cells, A. laidlawii PG8R was subcultured into Edward's medium containing an appropriate concentration of ciprofloxacin. Resistant cultures of A. laidlawii PG8R were plated onto solid agar that contained appropriate concentrations of ciprofloxacin and individual colonies were analyzed.

2.3. Determination of the MIC. To determine the MIC, the original mycoplasma cell culture was passaged in broth medium with different concentrations of ciprofloxacin: 0.1, $0.2,0.3,0.4,0.5,0.6,0.7,0.8,0.9,1.0$, and $1.5 \mu \mathrm{g} \mathrm{mL}^{-1}$. The MIC values were determined based on three independent replicates.

2.4. Transmission Electron Microscopy and Atomic Force Microscopy. Transmission electron microscopy was performed according to the method of Cole [19]. Samples were fixed with $2.5 \%$ glutaraldehyde ("Fluka," Germany) in $0.1 \mathrm{M}$ phosphate-buffered saline (PBS) ( $\mathrm{pH} \mathrm{7.2)} \mathrm{for} 2 \mathrm{~h}$. The fixed samples were then dehydrated using an acetone, ethanol, and propylene series, before postfixing in $0.1 \% \mathrm{OsO}_{4}$ with $25 \mathrm{mg} \mathrm{mL}^{-1}$ of saccharose. After treatment with epoxy resin ("Serva," Switzerland), ultrathin sections were cut using an LKB-III ultramicrotome (Sweden), which were stained with uranyl acetate for $10 \mathrm{~min}$ and lead citrate for $10 \mathrm{~min}$. The stained samples were examined using a JEM-1200EX transmission electron microscope ("Joel," Japan).

To prepare samples for atomic force microscopy (AFM) analysis, $1 \mathrm{~mL}$ aliquots of the A. laidlawii PG8 cells and
EVs were centrifuged at $12000 \mathrm{rpm}$ for $20 \mathrm{~min}$ at room temperature. The pellets were resuspended in $1 \mathrm{~mL}$ of $\mathrm{PBS} \times 1$ ( $\mathrm{pH}$ 7.2). The cells were centrifuged once more at $12000 \mathrm{rpm}$ for $15 \mathrm{~min}$ at room temperature and repeatedly resuspended in $0.5 \mathrm{~mL}$ of the same buffer. The prepared cells were placed onto mica (Advanced Technologies Center, Moscow, Russia) where the upper layer was removed. The cells were air-dried and washed twice with redistilled water. The samples were airdried after each wash.

AFM imaging was performed using a Solver $\mathrm{P} 47 \mathrm{H}$ atomic force microscope (NT-MDT, Moscow, Russia), which operated in the tapping mode with fpN11S cantilevers $(r \leq 10 \mathrm{~nm}$, Advanced Technologies Center, Moscow, Russia). The height, Mag (signal from lock-in amplifier), RMS (signal from RMS detector), and phase (signal from the phase detector) were set using the Nova 1.0.26 RC1 software (NT-MDT). The scan rate was $1 \mathrm{~Hz}$ and the image resolution was $512 \times 512$ pixels. Numerical data were expressed as the mean \pm SE.

2.5. Accumulation of Ciprofloxacin. The presence of antibiotics in the EVs was determined using a fluorimetric method $[20,21]$. The fluorescence was measured with a Fluorolog 3 spectrofluorometer (Horiba Jobin Yvon SAS, France) at an excitation wavelength of $282 \mathrm{~nm}$ and an emission wavelength of $442 \mathrm{~nm}$. A blank sample that contained an equivalent amount of cells without the addition of ciprofloxacin was used as a control. The results were expressed as nanograms of ciprofloxacin per milligram of protein. All of the experiments were performed at least three times to ensure reproducibility. The mean and standard error were calculated.

2.6. Antimicrobial Activity. The Kirby-Bauer disc diffusion method with a ciprofloxacin-sensitive test strain of Staphylococcus aureus was used to evaluate the bacteriostatic effects of A. laidlawii EVs [22].

2.7. Isolation of EVs. EVs were isolated from A. laidlawii cultures (logarithmic growth phase) according to the method of Kolling and Matthews, with some modifications [9, 14, 23]. The cells were precipitated by centrifugation at $5000 \mathrm{~g}$ for $20 \mathrm{~min}$. The supernatant was filtered through a $0.10 \mu \mathrm{m}$ filter (Sartorius Minisart, France), and the filtrate was concentrated 20-fold by ultrafiltration (Vivacell 100, 100000 MWCO, "Sartorius Stedim Biotech GmbH", Germany). Vesicles were collected by ultracentrifugation $\left(100000 \mathrm{~g}, 1 \mathrm{~h}, 8^{\circ} \mathrm{C}\right)$ with a MLA-80 rotor (Beckman Coulter Optima MAX-E), twice washed, resuspended in buffer (50 $\mathrm{mM}$ Tris- $\mathrm{HCl}, \mathrm{pH}=7,4$; $150 \mathrm{mM} \mathrm{NaCl} ; 2 \mathrm{mM} \mathrm{MgCl}_{2}$ ) and filtered through a sterile filter (Sartorius Minisart, France) with a pore size of $200 \mathrm{~nm}$.

2.8. Isolation of DNA from Cells and EVs. DNA was isolated from mycoplasma cells according to the method of Maniatis [24]. DNA was isolated from EVs using a commercial DNAexpress kit ("Litekh," Moscow). Before extracting the nucleic acids, the EV samples were treated with DNAse I and RNase (at $37^{\circ} \mathrm{C}$ for $30 \mathrm{~min}$ ).

2.9. Sequencing. The PCR primers were constructed by NSF Litekh (Moscow, Russia) using the nucleotide sequences 


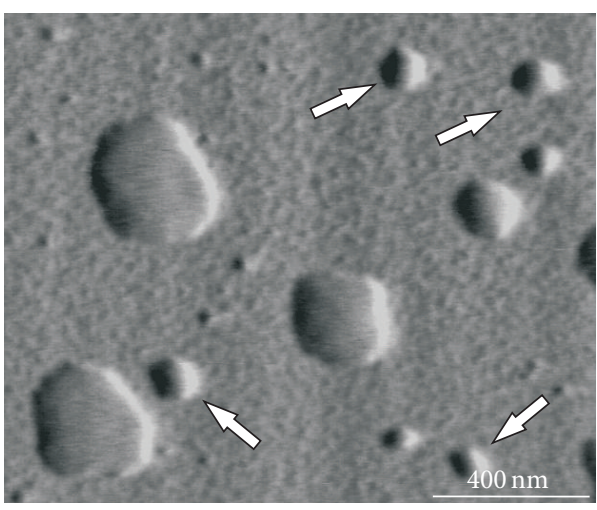

(a)

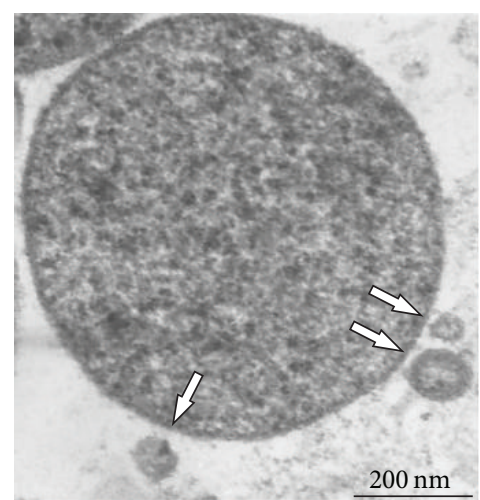

(b)

FIGURE 1: Atomic force microscopy (a) and transmission electron microscopy (b) images of Acholeplasma laidlawii PG8 cells and extracellular vesicles (indicated by arrows).

of A. laidlawii PG8A genes (GenBank accession number NC_010163): ftsZ (AlalF $5^{\prime}$-ggtttttggatttaacgatg-3' AlalR $5^{\prime}$ gcttccgcctcttttattt- $\left.3^{\prime}\right)$; spacer $16 \mathrm{~S}-23 \mathrm{~S}$ of ribosome operon (A16LF $5^{\prime}$-ggaggaaggtggggatgacgtcaa-3' A23LR $5^{\prime}$-ccttaggagatggtcctcctatcttcaaac- $\left.3^{\prime}\right)$; and parC (GenBank accession number NC_010163) (AqF15: $5^{\prime}$-ata cgc at ggg aca aat g- $3^{\prime}$; AqR15: $5^{\prime}$-ggt tct tgt tcc tca tca tca-3 $3^{\prime}$. PCR was performed in the following regime: for primers Alal, $95^{\circ} \mathrm{C}, 3 \min \left(95^{\circ} \mathrm{C}\right.$, $\left.20 \mathrm{sec} ; 52^{\circ} \mathrm{C}, 20 \mathrm{sec} ; 72^{\circ} \mathrm{C}, 20 \mathrm{sec}\right)(30 \mathrm{cycles}) ; 72^{\circ} \mathrm{C}, 10 \mathrm{~min}$. For primers A23LR, $95^{\circ} \mathrm{C}, 3 \mathrm{~min}\left(95^{\circ} \mathrm{C}, 5 \mathrm{sec} ; 63^{\circ} \mathrm{C}, 5 \mathrm{sec} ; 72^{\circ} \mathrm{C}\right.$, $20 \mathrm{sec}$ ) $\left(30\right.$ cycles); $72^{\circ} \mathrm{C}, 5 \mathrm{~min}$. For primers Aq15, $95^{\circ} \mathrm{C}, 3 \mathrm{~min}$ $\left(95^{\circ} \mathrm{C}, 5 \mathrm{sec} ; 63^{\circ} \mathrm{C}, 5 \mathrm{sec} ; 72^{\circ} \mathrm{C}, 5 \mathrm{sec}\right)(35 \mathrm{cycles}) ; 72^{\circ} \mathrm{C}, 5 \mathrm{~min}$.

DNA sequencing was performed using BigDye Terminator v3.1 Cycle Sequencing kits ("Applied Biosystems," USA) and a 3130 Genetic Analyzer ("Applied Biosystems," USA). The nucleotide sequences were analyzed using the Sequencing Analysis 5.3.1 program ("Applied Biosystems," USA) and the NCBI (National Center for Biotechnology Information, http://blast.ncbi.nlm.nih.gov/Blast.cgi) database.

\section{Results and Discussion}

To determine the role of membrane EVs in the development of resistance to fluoroquinolones in A. laidlawii, this study used mycoplasma strains with different levels of susceptibility to ciprofloxacin, that is, PG8 (MIC $0.5 \mu \mathrm{g} / \mathrm{mL}$ ) and PG8R (MIC $1 \mu \mathrm{g} / \mathrm{mL}$ ). A. laidlawii strain PG8R was obtained by stepwise selection from A. laidlawii PG8. The analysis of micrographs obtained using variants of transmissive and probe microscopy showed that the mycoplasma cells secreted EVs in normal conditions (Figures 1 and 2(a)). The treatment of the mycoplasma culture with ciprofloxacin elicited a significant increase in the level of vesiculation (sixfold) (Figure 2(b)). The level of vesiculation in A. laidlawii PG8R was significantly higher than that in A. laidlawii PG8. Recently, similar results were obtained with Pseudomonas aeruginosa [25] in another study, which also showed that EVs were involved with the traffic of antibiotics, because the EVs produced by the bacterial cells contained gentamicin [26].
The present study showed that after A. laidlawii was cultured in a medium that contained ciprofloxacin, the EVs produced by the mycoplasma contained the antibiotic $(0.66 \pm$ $0.15 \mathrm{ng} / \mathrm{mg}$ of protein). The EVs that contained ciprofloxacin also exhibited bacteriostatic effects against a clinical isolate of ciprofloxacin-sensitive $S$. aureus (Table 1). These results suggest that the EVs of $A$. laidlawii may be involved with the export of ciprofloxacin and possibly with the mechanism of mycoplasma adaptation to antibiotics.

The main mechanisms that facilitate the development of resistance to quinolones in bacteria are considered to be associated with mutations in specific loci, that is, the quinolone-resistance-determining regions (QRDRs) of genes that encode antibiotic-targeted proteins $[7,27,28]$. The most significant locus is the QRDR in parC of DNA topoisomerase IV $[7,29]$. To determine whether this locus was involved with the increased resistance to ciprofloxacin in A. laidlawii PG8R, the parC QRDRs of the mycoplasma strains were amplified, cloned, and sequenced. The DNA was extracted from mycoplasmas cultivated in broth culture, which were obtained from a single colony grown on solid medium. The DNA sequences isolated from the cells of A. laidlawii PG8 and A. laidlawii PG8R were not identical (Figure 3(a)). The nucleotide sequence of parC QRDR from A. laidlawii PG8R contained a $\mathrm{C} \rightarrow \mathrm{T}$ transition at position 272 , which caused a serine to leucine (Ser (91) Leu) replacement in the amino acid sequence of the antibiotic-targeted protein (Figure 3(b)). Previously, this mutation was found in a strain of $A$. laidlawii PG8B, which was characterized by its elevated resistance to quinolones $(6-10 \mu \mathrm{g} / \mathrm{mL})$ [27]. Thus, the nucleotide sequence of the QRDR in the gene encoding the $\mathrm{C}$ subunit of DNA topoisomerase IV in A. laidlawii PG8R contained a sense mutation.

The development of resistance to quinolones in bacterial populations associated with point mutations in the QRDR of parC should lead to the rapid spread of the corresponding nucleotide sequences in bacterial communities. The main means of spreading antibiotic resistance genes in bacteria is horizontal transfer [30]. Recently, it was shown that the EVs 


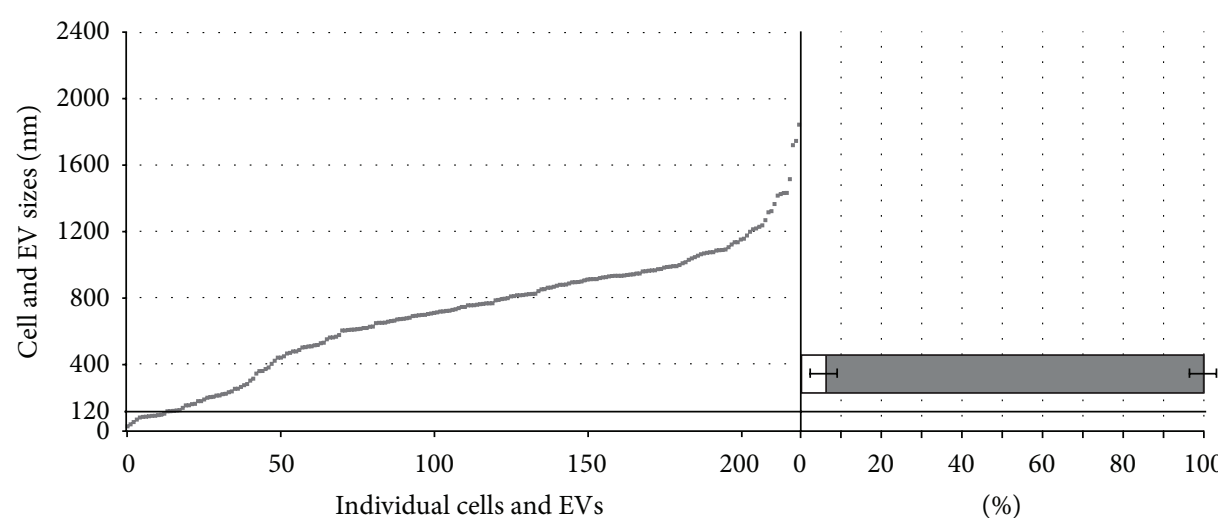

(a)

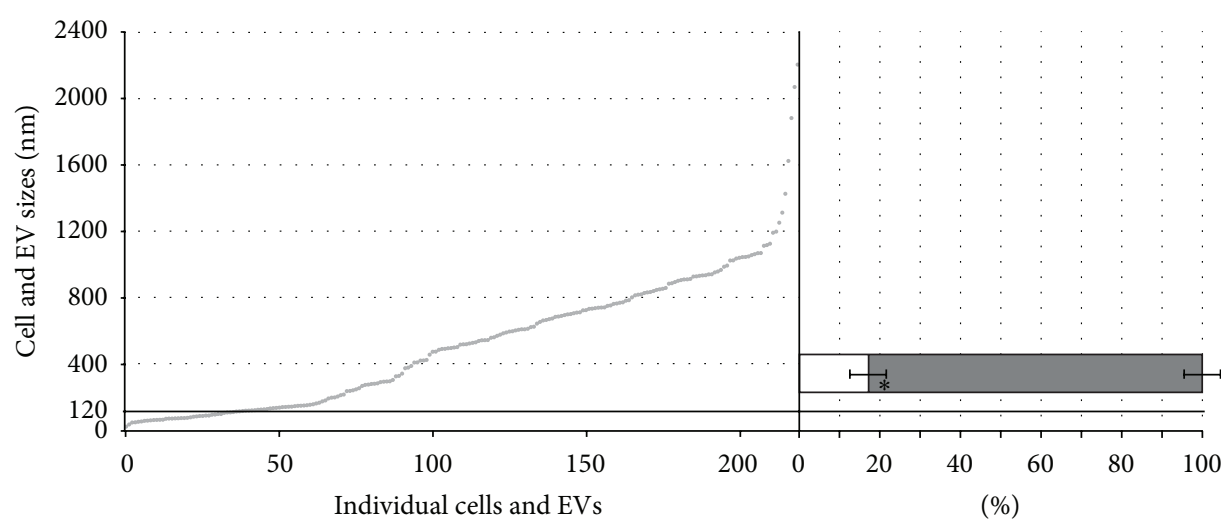

(c)

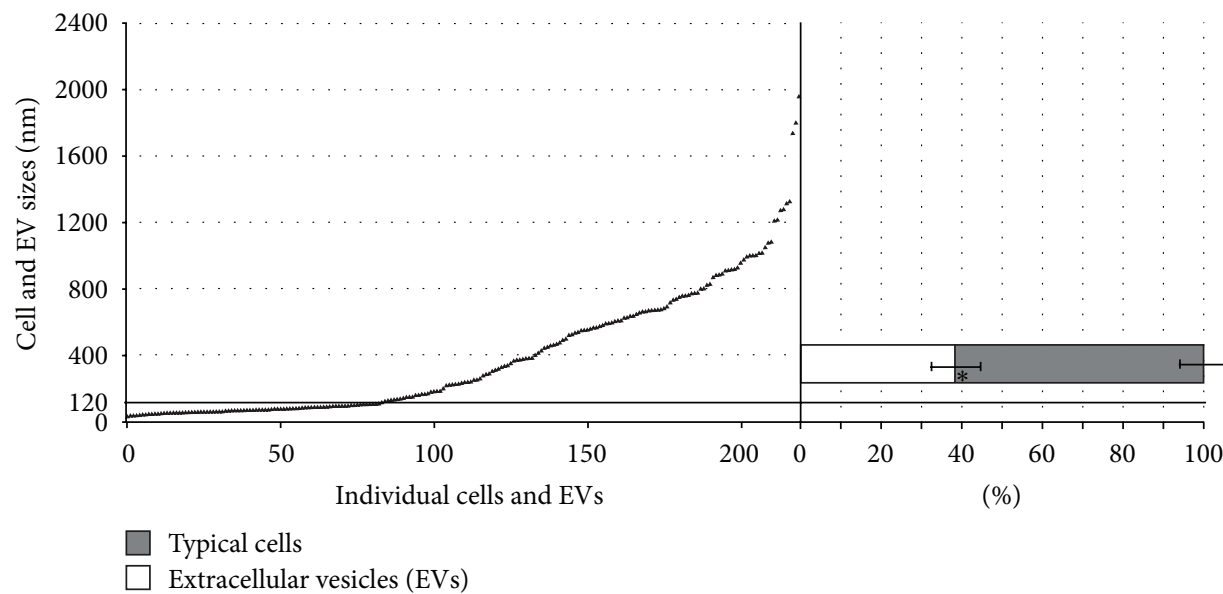

(e)

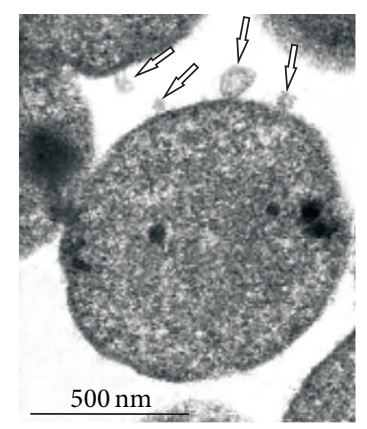

(b)

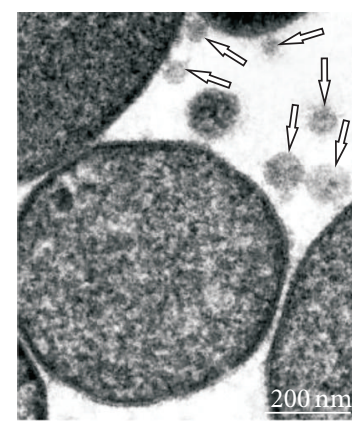

(d)

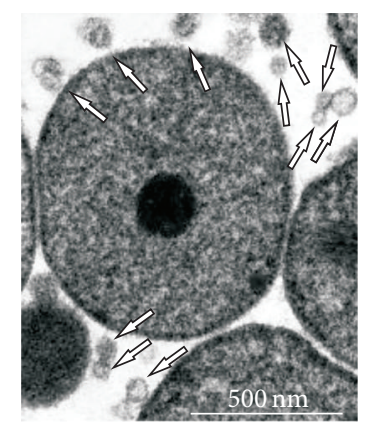

(f)

FIGURE 2: Relationships between typical cells and extracellular vesicles (EVs) (a, c, e) and transmission electron microscopy images (b, d, f) (extracellular vesicles (indicated by arrows)) of Acholeplasma laidlawii PG8 without ciprofloxacin (a, b), in the presence of antibiotic *** (c, d) and A. laidlawii PG8R (e,f) (according to transmission electron microscopy). Each point corresponds to the linear size of individual cells or EVs. ${ }^{*} P<0.05$. ${ }^{* *}$ Treatment with ciprofloxacin for $80 \mathrm{~min}$.

of some bacteria may allow the traffic of genes that encode antibiotic-targeted proteins, thereby mediating the horizontal transfer of nucleotide sequences that determine antibiotic resistance in bacterial populations $[31,32]$.

Thus, to estimate the potential participation of the mycoplasma EVs in the traffic of the mutant gene that encoded the fluoroquinolone-targeted protein, the EVs of $A$. laidlawii PG8 and A. laidlawii PG8R were tested to determine the presence of the nucleotide sequences of parC QRDR. Previously $[9,14]$, we reported that the EVs of A. laidlawii PG8 contained the nucleotide sequences of several genes, which can be used as specific markers of the mycoplasma EVs, thereby allowing the detection of EVs and providing a control to detect the absence of bacterial cells in EV 


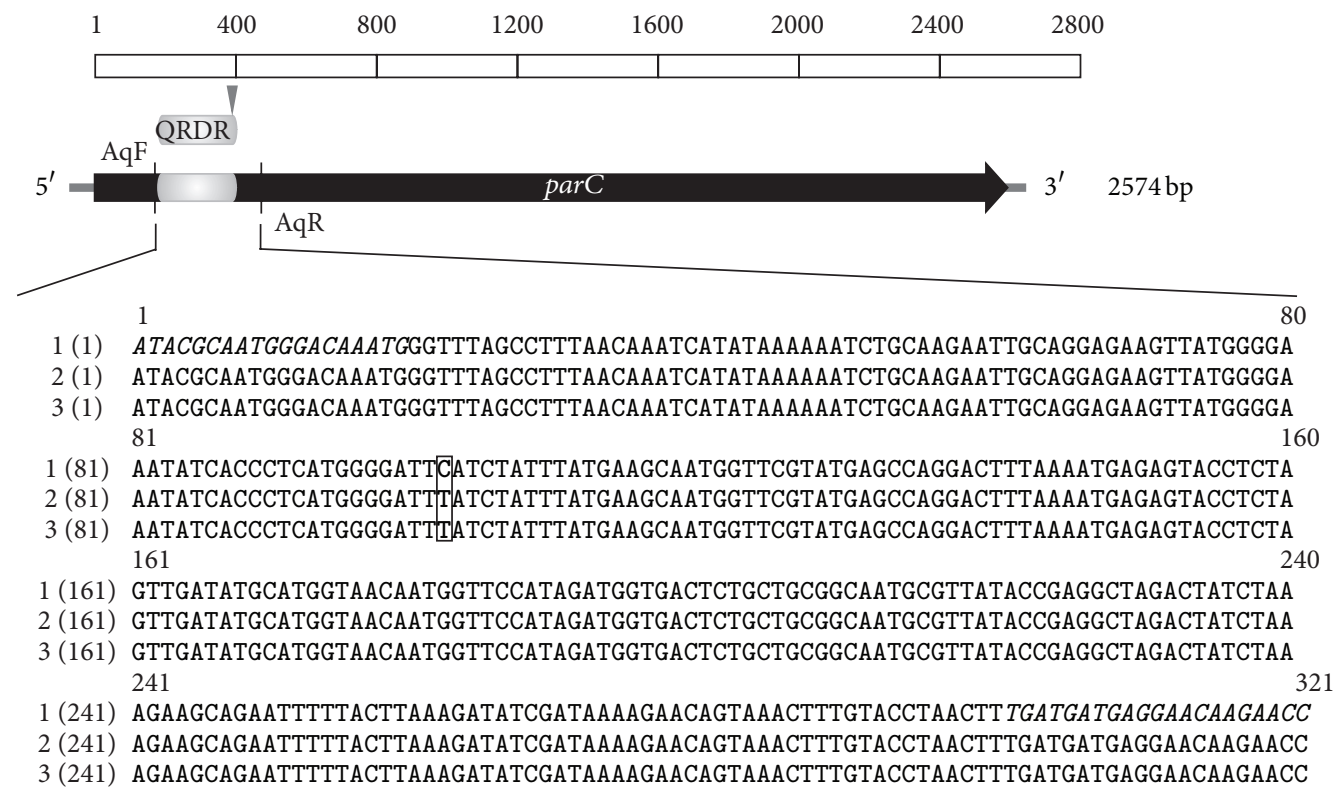

(a)

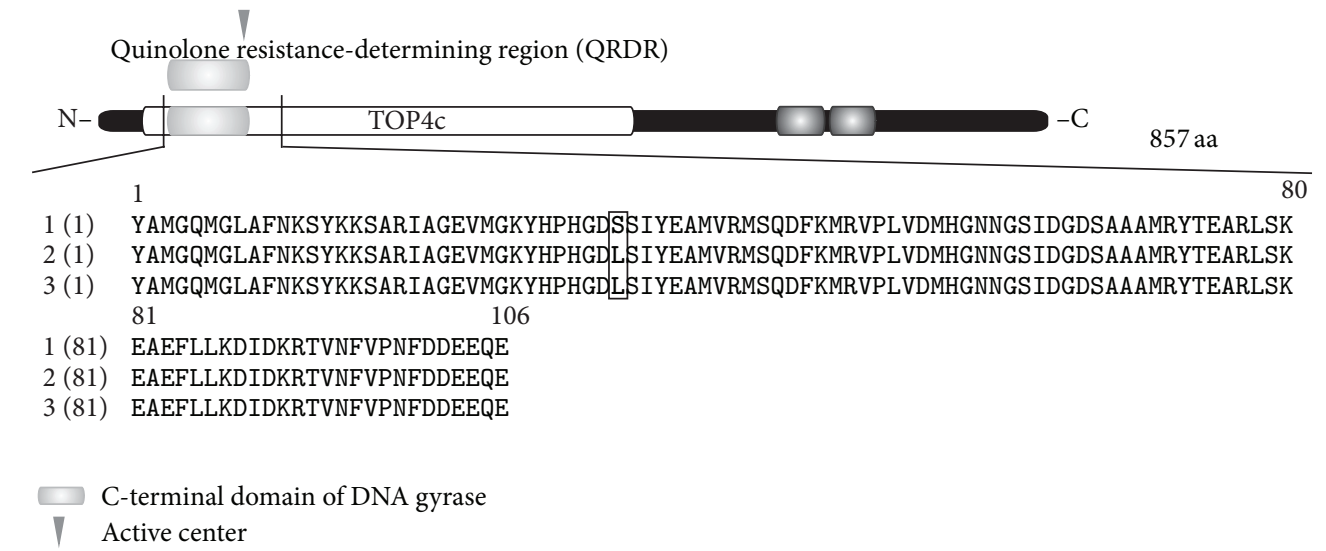

(b)

FIGURE 3: Results of the alignments of the nucleotide (a) and amino acid (b) sequences of the parC gene of Acholeplasma laidlawii PG8 cells (1), cells of A. laidlawii PG8R (2), and the extracellular vesicles of A. laidlawii PG8R (3). Italics indicate the sequences of the forward and reverse primers. Nucleotide substitutions and amino acid replacements are enclosed in rectangles, the active site.

TABLE 1: Ciprofloxacin content and bacteriostatic activities of the extracellular vesicles of Acholeplasma laidlawii PG8R.

\begin{tabular}{lccc}
\hline Test samples & $\begin{array}{c}\text { Ciprofloxacin } \\
(5 \mathrm{~g} / \mathrm{mL})\end{array}$ & \multicolumn{2}{c}{$\begin{array}{c}\text { Extracellular vesicles of } \\
\text { A. laidlawii PG8R }\end{array}$} \\
& & Native & Destroyed \\
\hline $\begin{array}{l}\text { Ciprofloxacin } \\
\text { content, ng/mg } \\
\text { of protein }\end{array}$ & - & - & $0.66 \pm 0.15$ \\
$\begin{array}{l}\text { Lysis area } \\
(\mathrm{mm})^{* *}\end{array}$ & $21.2 \pm 0.3$ & $3.4 \pm 0.21$ & $8.8 \pm 0.16$ \\
\end{tabular}

${ }^{*}$ Mean \pm standard deviation.

${ }^{* *}$ Native extracellular vesicles of $A$. laidlawii PG8R were used as a control to estimate the bacteriostatic effects of the vesicle components. preparations. These data were considered when conducting this study.

PCR using primers that amplified the nucleotide sequences of marker genes in the EVs of A. laidlawii PG8 and parC QRDR from the mycoplasmas detected the parC QRDR-specific PCR signal, where DNA obtained from the EVs of A. laidlawii PG8 and A. laidlawii PG8R were used as templates (Figure 4). The sequencing data indicated that the PCR signals corresponded to parC QRDR from the mycoplasmas. The $\mathrm{C} \rightarrow \mathrm{T}$ transition at position 272 was also detected with A. laidlawii PG8R (Figure 3). Thus, this study demonstrated that A. laidlawii PG8 and A. laidlawii PG8R produced EVs that contained parC QRDR nucleotide sequences, which were copies of the gene sequences from the respective mycoplasma strains.

A. laidlawii PG8R EVs mediated the export of a parC QRDR sequence with a $\mathrm{C} \rightarrow \mathrm{T}$ transition at position 272, 


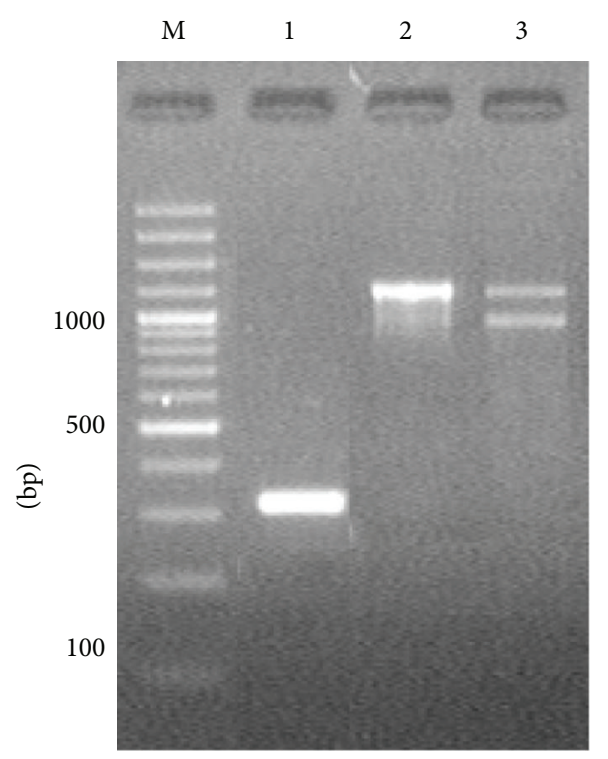

(a)

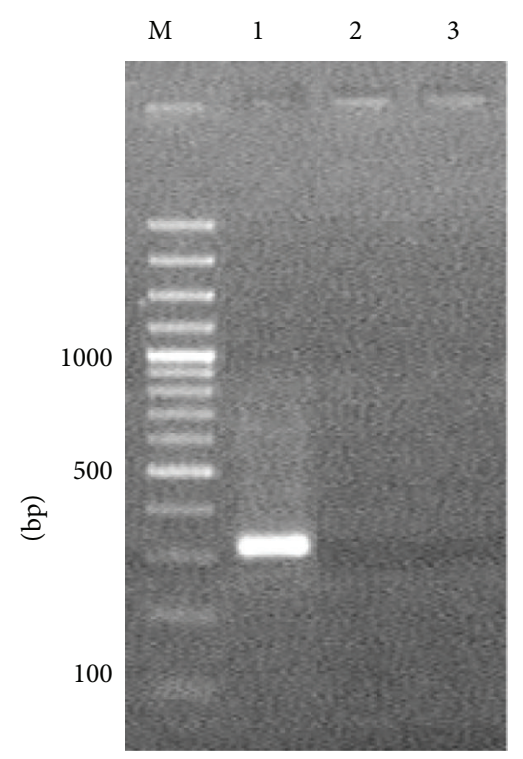

(b)

FIGURE 4: Electrophoregrams of the amplification products of the nucleotide sequences of parC (1), ftsZ (2), and A23LR (3) of Acholeplasma laidlawii PG8, which were obtained by PCR using the total DNA (as a template) isolated from the cells (a) and extracellular vesicles (b) of $A$. laidlawii PG8R. M: molecular weight marker.

which produced a substitution in the amino acid sequence of the antibiotic-targeted protein. This suggests the possibility that EVs can spread the mutant gene in bacterial communities via horizontal transfer. This capacity was demonstrated recently in E. coli and P. aeruginosa model systems [33]. A study of similar processes in A. laidlawii model systems has yet to be made.

\section{Conclusions}

This study showed that the EVs secreted by A. laidlawii cells are involved with the development of the resistance to ciprofloxacin. The results also indicate that the mechanism of antibiotic resistance in this mycoplasma was associated with a mutation in a gene that encoded a quinolone-targeted protein, while the vesiculation level was also modulated. Furthermore, the EVs of A. laidlawii mediated the export of the nucleotide sequences of the gene that encoded the ciprofloxacin-targeted protein, as well as the antibiotic. These results demonstrate the necessity of applying appropriate approaches to the development of effective methods for controlling mycoplasma infections, as well as contamination of cell cultures and vaccines.

\section{Conflict of Interests}

The authors declare that there is no conflict of interests regarding the publication of this paper.

\section{Acknowledgments}

This work was supported by the grant of the Ministry of Education and Science of the Russian Federation (the 8048
Agreement), Russian Foundation for Basic Research 11-0401406a, and 12-04-01052a, 12-04-31396, the Grant of President of Russian Federation (MK-3823.2023.4), and the Grant for state support of leading scientific schools of the Russian Federation (no. NSH-825.2012.4). The authors are grateful to G. F. Shaimardanova $(\mathrm{PhD})$ for her help in the transmissive electron microscopy.

\section{References}

[1] M. Folmsbee, G. Howard, and M. Mcalister, "Nutritional effects of culture media on mycoplasma cell size and removal by filtration," Biologicals, vol. 38, no. 2, pp. 214-217, 2010.

[2] H. M. Windsor, G. D. Windsor, and J. H. Noordergraaf, “The growth and long term survival of Acholeplasma laidlawii in media products used in biopharmaceutical manufacturing," Biologicals, vol. 38, no. 2, pp. 204-210, 2010.

[3] C. C. Uphoff and H. G. Drexler, "Detection of mycoplasma contaminations," Methods in Molecular Biology, vol. 946, pp. 113, 2013.

[4] C. Bébéar, S. Pereyre, and O. Peuchant, "Mycoplasma pneumoniae susceptibility and resistance to antibiotics," Future Microbiology, vol. 6, no. 4, pp. 423-431, 2011.

[5] E. Mariotti, F. D’alessio, P. Mirabelli, R. di Noto, G. Fortunato, and L. del Vecchio, "Mollicutes contamination: a new strategy for an effective rescue of cancer cell lines," Biologicals, vol. 40, no. 1, pp. 88-91, 2012.

[6] S. Raherison, P. Gonzalez, H. Renaudin, A. Charron, C. Bébéar, and C. M. Bébéar, "Evidence of active efflux in resistance to ciprofloxacin and to ethidium bromide by Mycoplasma hominis," Antimicrobial Agents and Chemotherapy, vol. 46, no. 3, pp. 672-679, 2002.

[7] Y. Yamaguchi, M. Takei, R. Kishii, M. Yasuda, and T. Deguchi, "Contribution of topoisomerase IV mutation to 
quinolone resistance in Mycoplasma genitalium," Antimicrob Agents Chemother, vol. 57, no. 4, pp. 1772-1776, 2013.

[8] D. L. Couldwell, K. A. Tagg, N. J. Jeoffreys, and G. L. Gilbert, "Failure of moxifloxacin treatment in Mycoplasma genitalium infections due to macrolide and fluoroquinolone resistance," International Journal of STD \& AIDS, vol. 24, no. 10, pp. 822$828,2013$.

[9] V. M. Chernov, O. A. Chernova, A. A. Mouzykantov et al., "Extracellular vesicles derived from Acholeplasma laidlawii PG8," TheScientificWorldJournal, vol. 11, pp. 1120-1130, 2011.

[10] V. M. Chernov, O. A. Chernova, E. S. Medvedeva et al., "Unadapted and adapted to starvation Acholeplasma laidlawii cells induce different responses of Oryza sativa, as determined by proteome analysis," Journal of Proteomics, vol. 74, no. 12, pp. 2920-2936, 2011.

[11] M. F. Nicolás, F. G. Barcellos, P. N. Hess, and M. Hungria, "ABC transporters in Mycoplasma hyopneumoniae and Mycoplasma synoviae: insights into evolution and pathogenicity," Genetics and Molecular Biology, vol. 30, no. 1, pp. 202-211, 2007.

[12] S. Razin and L. Hayflick, "Highlights of mycoplasma researchan historical perspective," Biologicals, vol. 38, no. 2, pp. 183-190, 2010.

[13] I. G. Scripal, Microorganisms-Agents of the Plant Diseases, Edited by V. I. Bilay, Naukova Dumka, Kiev, Ukraine, 1989.

[14] V. M. Chernov, O. A. Chernova, A. A. Mouzykantov et al., "Extracellular membrane vesicles and phytopathogenicity of Acholeplasma laidlawii PG8," The Scientific World Journal, vol. 2012, Article ID 315474, 6 pages, 2012.

[15] A. Kulp and M. J. Kuehn, "Biological functions and biogenesis of secreted bacterial outer membrane vesicles," Annual Review of Microbiology, vol. 64, pp. 163-184, 2010.

[16] J. W. Schertzer and M. Whiteley, "Bacterial outer membrane vesicles in trafficking, communication and the host-pathogen interaction," Journal of Molecular Microbiology and Biotechnology, vol. 23, pp. 118-130, 2013.

[17] O. Ciofu, T. J. Beveridge, J. Kadurugamuwa, J. WaltherRasmussen, and N. Hoiby, "Chromosomal $\beta$-lactamase is packaged into membrane vesicles and secreted from Pseudomonas aeruginosa," Journal of Antimicrobial Chemotherapy, vol. 45, no. 1, pp. 9-13, 2000.

[18] J. Lee, E. Y. Lee, S. H. Kim et al., "Staphylococcus aureus extracellular vesicles carry biologically active $\beta$-lactamase," Antimicrobial Agents and Chemotherapy, vol. 57, pp. 2589-2595, 2013.

[19] R. M. Cole, Methods in Mycoplasmology, Edited by S. H. Razin, J. G. Tully, Academic Press, New York, NY, USA, 1983.

[20] J. S. Chapman and N. H. Georgopapadakou, "Fluorometric assay for fleroxacin uptake by bacterial cells," Antimicrobial Agents and Chemotherapy, vol. 33, no. 1, pp. 27-29, 1989.

[21] Y. Sun, M. Dai, H. Hao et al., "The role of RamA on the development of ciprofloxacin resistance in Salmonella enterica serovar Typhimurium," PLoS ONE, vol. 6, no. 8, Article ID e23471, 2011.

[22] "Performance standards for antimicrobial susceptibility testing," CLSI Approved Standard M100-S15, Clinical and Laboratory Standards Institute, Wayne, Pa, USA, 2005.

[23] G. L. Kolling and K. R. Matthews, "Export of virulence genes and Shiga toxin by membrane vesicles of Escherichia coli O157:H7," Applied and Environmental Microbiology, vol. 65, no. 5, pp. 1843-1848, 1999.
[24] T. Maniatis, E. E. Fritsch, and J. Sabrook, Molecular Cloning. A Laboratory Manual, Cold Spring Harbor, NY, USA, 1982.

[25] R. Maredia, N. Devineni, P. Lentz et al., "Vesiculation from Pseudomonas aeruginosa under SOS," The Scientific World Journal, vol. 2012, Article ID 402919, 8 pages, 2012.

[26] J. L. Kadurugamuwa and T. J. Beveridge, "Bacteriolytic effect of membrane vesicles from Pseudomonas aeruginosa on other bacteria including pathogens: conceptually new antibiotics," Journal of Bacteriology, vol. 178, no. 10, pp. 2767-2774, 1996.

[27] K. D. Taganov, A. E. Gushchin, N. I. Abramycheva, and V. M. Govorun, "Role of mutations in the a-subunit of Acholeplasma laidlawii PG-8B topoisomerase IV in formation of resistance to fluoroquinolones," Molekuliarnaia Genetika, Mikrobiologiia I Virusologiia, no. 2, pp. 30-33, 2000 (Russian).

[28] J. Ruiz, "Mechanisms of resistance to quinolones: target alterations, decreased accumulation and DNA gyrase protection," Journal of Antimicrobial Chemotherapy, vol. 51, no. 5, pp. 11091117, 2003.

[29] C. Bébéar, H. Renaudin, A. Charron, J. M. Bové, C. Bébéar, and J. Renaudin, "Alterations in topoisomerase IV and DNA gyrase in quinolone-resistant mutants of Mycoplasma hominis obtained in vitro," Antimicrobial Agents and Chemotherapy, vol. 42, no. 9, pp. 2304-2311, 1998.

[30] M. Ip, S. S. L. Chau, F. Chi, J. Tang, and P. K. Chan, "Fluoroquinolone resistance in atypical pneumococci and oral streptococci: evidence of horizontal gene transfer of fluoroquinolone resistance determinants from Streptococcus pneumoniae," Antimicrobial Agents and Chemotherapy, vol. 51, no. 8, pp. 2690-2700, 2007.

[31] S. Yaron, G. L. Kolling, L. Simon, and K. R. Matthews, "Vesiclemediated transfer of virulence genes from Escherichia coli O157:H7 to other enteric bacteria," Applied and Environmental Microbiology, vol. 66, no. 10, pp. 4414-4420, 2000.

[32] C. Rumbo, E. Fernández-Moreira, M. Merino et al., "Horizontal transfer of the OXA-24 carbapenemase gene via outer membrane vesicles: a new mechanism of dissemination of carbapenem resistance genes in Acinetobacter baumannii," Antimicrobial Agents and Chemotherapy, vol. 55, no. 7, pp. 30843090, 2011.

[33] A. J. Manning and M. J. Kuehn, "Contribution of bacterial outer membrane vesicles to innate bacterial defense," $B M C$ Microbiology, vol. 11, article 258, 2011. 

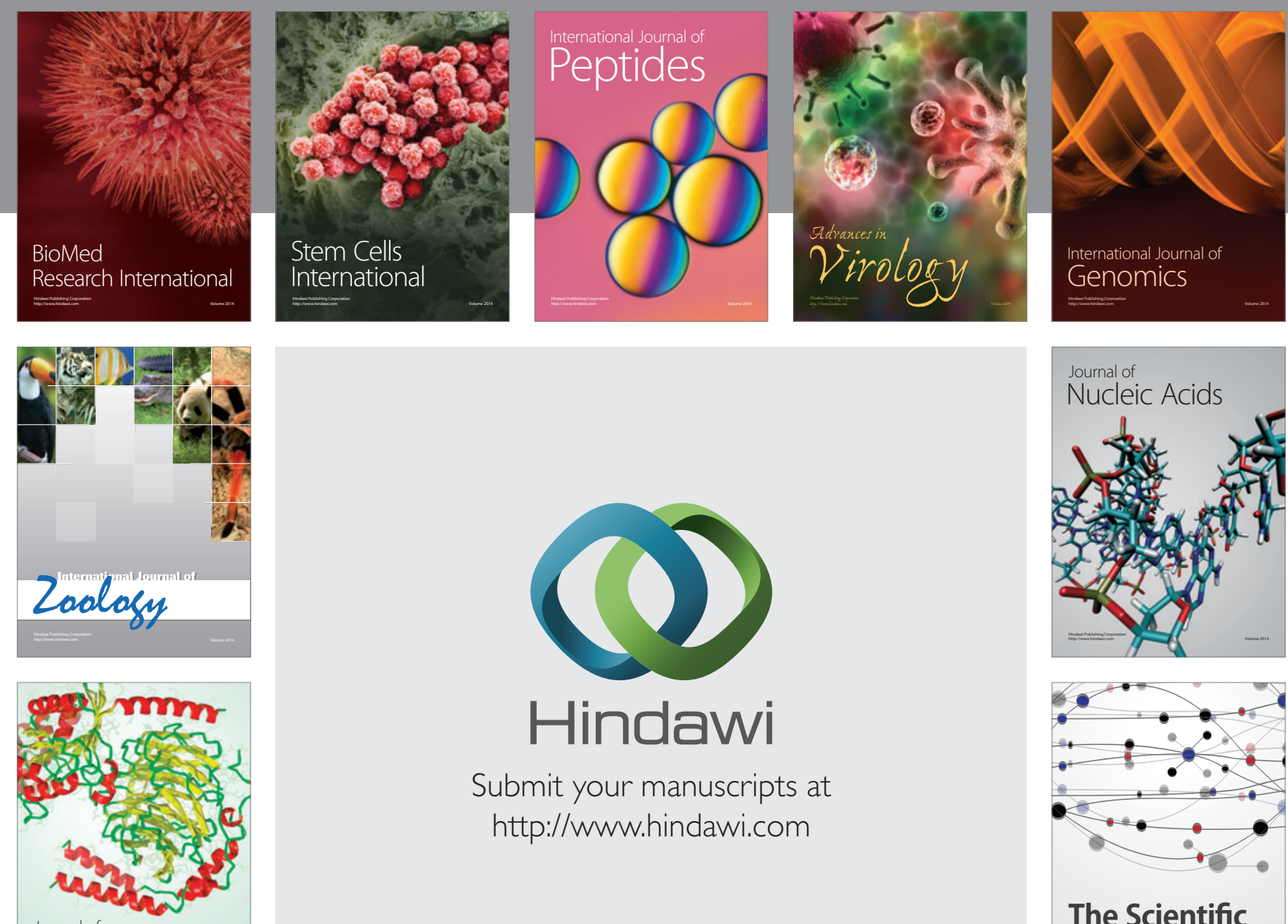

Submit your manuscripts at

http://www.hindawi.com

Journal of
Signal Transduction
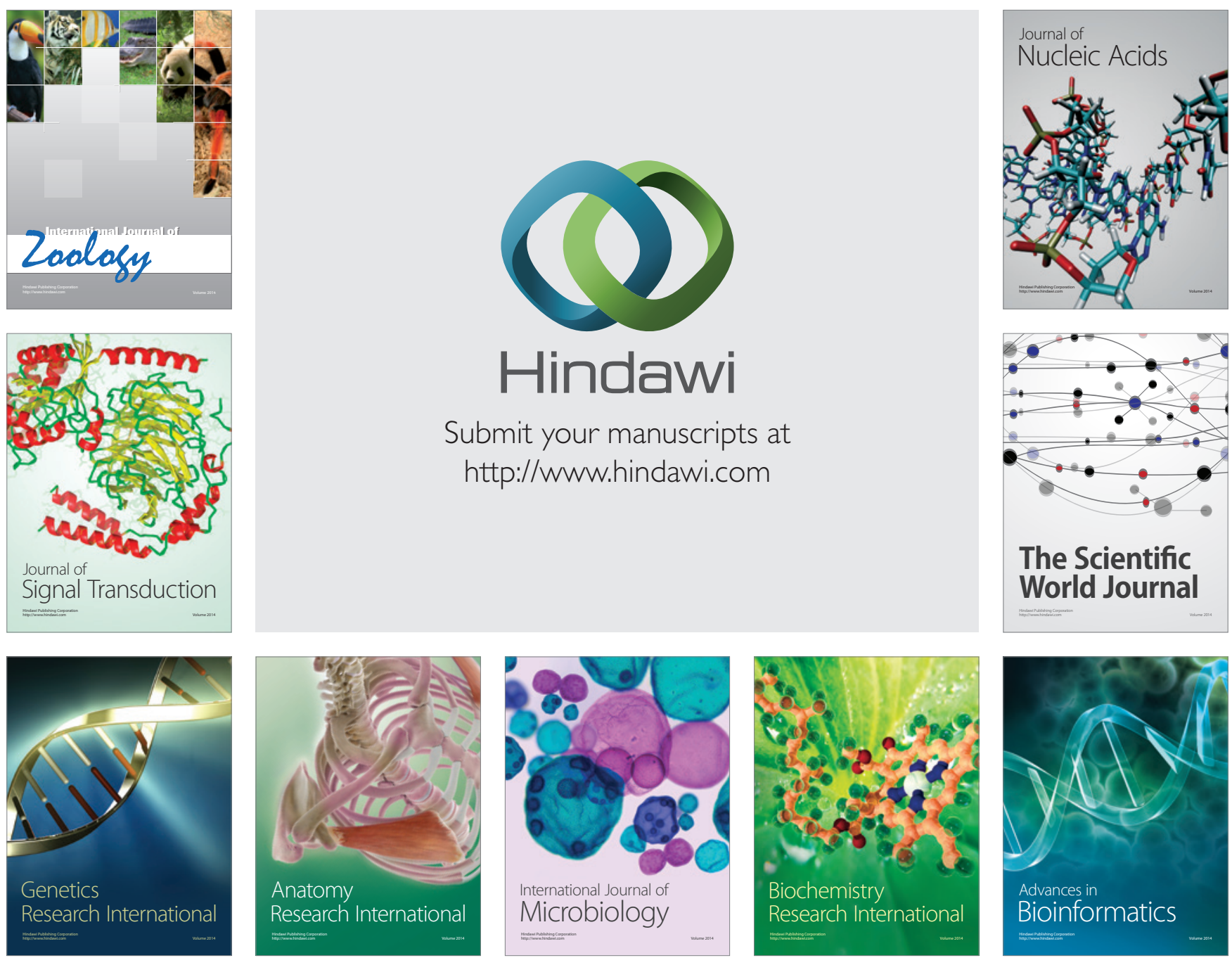

The Scientific World Journal
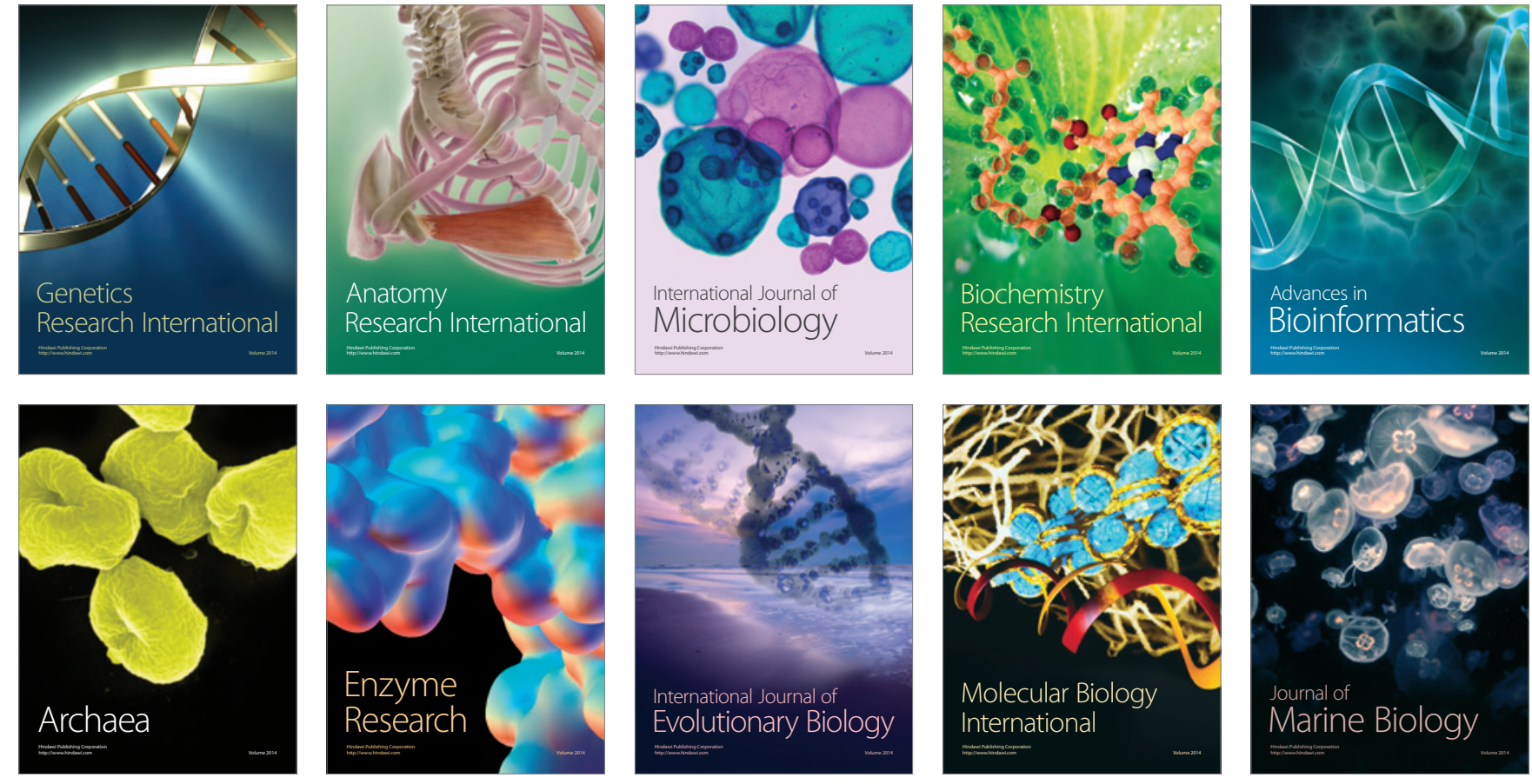